\title{
Globalization and Inculturation an African Perspective
}

\author{
Kas omo Danie, ${ }^{1, *}$, Mus yoka Joseph ${ }^{2}$ \\ ${ }^{1}$ Maseno University, Department of Religion, Theology and Philosophy , Kenya \\ ${ }^{2}$ South Eastern University College of Nairobi, Department of Humanities , Kenya
}

\begin{abstract}
I feel very challenged to tackle this topic. The reason is simple. Both key words in the topic, namely inculturation and globalization, need volumes in order to make oneself fully understood. I shall, therefore, give my working definition and understanding of the two concepts and then strongly argue that they can and indeed must creatively live together in a marriage that is both ratified and consummated! The entire article is based on six main arguments. In the first place I argue that in defining globalization, we must clearly distinguish the positive from the negative nature and content of globalization. I shall deal with globalization fro $m$ the point of view of its effects on the poor, the vulnerable, the marginalised and the powerless, in a word the victims of society, who are easily exp loited, oppressed, suppressed and alienated and isolated. I shall use views and perceptions of these victims to show what they consider positive and negative in globalization and what their hopes and fears are in this regard.The second argument, which runs through the paper, concerns the radical move from the narrow and classical understanding of inculturation to a new, dynamic, holistic and rich definition of inculturation. The fifty years of the inculturation movement, if we are to begin fro m 1953, Lea Pretres No ir S'Interrogent, have seen great strides in the concept and reality of inculturation. Incultuaration is no longer a concept found in universities, but one on the ground among people and in their daily lives and concrete situations. It is this new understanding of inculturation wh ich will be analyzed in view of globalization. In the third place, I argue that the five models of inculturation currently in place can each absorb the positive elements of globalization, while at the same time strongly and powerfully resisting the negative elements. Globalization in this view is simply one of the factors to the context in place, which context should be taken into account in any effective and relevant inculturation. The fourth argument is directly addressed to those who would wish to use the excuse of globalization to re-impose the oppressive uniformity of some so-called developed countries or Older Churches on Africa and those who think that globalization means some people and some societies must think, create, and plan for others. This is not a new reality but a very old one. Within the Catholic Church, this thinking is often linked to the group of Cardinal Ottaviani during the Vatican II. It stands for Semper Idem: One universal church, one universal theology, philosophy, liturgy, spirituality, education, one mode of thinking and acting, one vision and one ethos! This so-called globalized thinking is neither universal nor orthodox. The fifth and last arguments relate to the creative manner in which authentic incultration should be done and promoted taking into serious account of what is taking place with in Africa, within each country and community in Africa and in the world at large. Globalization only challenges the method in which inculturation should be conceived, the method in which it should be implemented in a fully relevant way. It is therefore not a question of either choosing inculturation or globilisation, but rather of how inculturation must control the negative aspects of globalization, shine cut clearly over globalization and relate with it relevantly, creatively and profitably.
\end{abstract}

Keywords Africa, Church, Globolisation, Incultaration

\section{Introduction}

In considering globalization it is important to remember that the process has been long in history. Beginning from the $15^{\text {th }}$ century the victims of Africa have witnessed five types and stages of globalization and all of them have been very negative to the continent and its peoples. The first began with the Portuguese exploration in the second half of the $15^{\text {th }}$ century. New Continents and regions were 'discovered' for

* Corresponding author:

dkasomocounselling@yahoo.com (Kasomo Danie)

Published online at http://journal.sapub.org/ijas

Copyright (C) 2011 Scientific \& Academic Publishing. All Rights Reserved
Europe, massive immigrations of Europeans took place, and the lands of the indigenous peoples were taken, massacres of indigenous peoples took place and the stronger militarily took possession of those lands, leaving the inhabitants homeless or pushing them into forests.

Having created new opportunities in these new vast continents, the second globalization began. L Tea, sugar, cotton and tobacco had to be produced in these lands for sale in Europe. Africa was $r$ selected as the land to provide this free and slave labour. Globalization descended on Mother Africa with a cruelty and inhumanity, which shudders minds and hearts. Millions of black Africans were hunted, bought and shipped to the New Lands under until the end of the $19^{\text {th }}$ century. Under this globalization, millions of Africans died 
during wars and battles for capture of slaves, during the many months at the Coast awaiting arrival and departure of slave ships; during the long months of the voyage to the New lands and at arrival and during the slavery itself when masters and foremen had the power to kill any resisting slave.

As slave trade was being brought to an end, partly because it was no longer as profitable as it had been in the past centuries, and partly because of the massive campaigns by some small groups of Christians opposed to its immorality, the third major globalization was launched to replace slave trade. This was the globalization of colonialis $m$ of the 19th century. Africa was cut into pieces for most of the European countries to take a slice of the big cake. Minerals, ivory and raw material were exploited for the industrialized countries of the West. A colonial education system was put in place to control the 'natives'. Some countries tried to 'assimilate' a few rich and powerful Africans. By the time Africans began their liberation struggles their nationalistic movements for independence, this globalization had done a lot of harm.

One of the negative characteristics of being colonized is that the colonized often lose their assertion for full dignity and equality. Some people among the colonized make alliances with the colonizers for their selfish interests. Some of the colonized continue to 'demand' to be under the colonizers or be supervised $b$ them. These attitudes are responsible for the fourth form of oppressive globalization, known as neo-colonialis $\mathrm{m}$.

The present globalization, often summarized in the expression of a global village is the fifth one and it shares much in the disvalues of the previous four types of globalization. It cannot be properly and critically assessed unless it is historically situated in the four fore-going globalizations, whose impact still remain in Africa.

\section{Features of the Current Globalization}

It does not originate from Africa or Third World but from the First and the former Second Worlds, Europe and America.

It is often not prepared for dialogue with the local people. It considers its values beyond questioning. They are the 'values' of the contemporary society, of the global village.

$>$ It is not a process of equals or working on one moral standard, It often uses double standards to achieve what it stands for. A simple example can be found on the immigration rules. People from the globalization world can walk in any country, with or without a visa and they take it as a right. They are part of the emerging global village. An A frican wishing to go to study, visit, or work in any of these countries is subjected to very strict and often dehumanizing regulations! That is double standard in the promotion of the global village!

$>$ Globalization does not benefit all stakeholders equally; it benefits mainly the foreigners from Europe and America and their few collaborators in Africa but never the largest population, the victims.

> Globalization will use so many means to make itself present in any place and will not easily allow genuine critic is ms. Any one who tries to criticize it is called names, seen as one still living in the past, under the influence of bygone political and economic ideologies!

> Globalization uses the mass media extensively in a manner, which seems to be aimed at brainwashing, indoctrinisation of the victims.

All participants are invited to add on this list their perceptions of globalization as it presents itself in their various areas of work and thinking.

\section{Main Types of Globalization}

The phenomenon of globalization we are witnessing can be placed under the following categories, but all of them well nested together, each strengthening the other.

Economic globalization: This is the most evident type of globalization anywhere in the world; it is the Macdonnisation of the world. Because the Macdonna sandwitch is good and appetizing in America it must be exported everywhere in the world, reaching deep into the villages and made and served in exactly the same way. The same may be said of the Coca-Cola, Pepsi or Panadol! The economic globalization of the world is built on the International Monetary Fund, the World Bank and the World Trade Organization. The aim of th is aspect of globalization is to bring the whole world under one market system with free movement of capital and of products (1) The relation is one of domination-dependence between the rich and poor countries' (2). It is therefore a farm of economic colonialism.

Political globalization: This is used to support economic globalization, sometimes through use of military might. We live in an uni-polar world, and it uses its political power to support and promote its own economic interests. Even when we critically reflect on what is happening in the Great Lakes' Region, we should examine the contribution of globalization to our wars and instability.

Cultural globalization: seeks to spread the "gospel" of modern culture as a necessary underpinning of economic and political globalization.' A materialistic outlook on life and reality, a spirit of individualism and competition, an attitude for consumerism, an approach of autonomy in the name of science from ethical and religious control, profit-oriented commercial activity are some of the characteristics of this culture. There is also an ideal of unity as uniformity and intolerance of pluralism. Life is mechanized. This culture is ardently propagated by the media, controlled by business interests, through advertisement, propaganda, and selective information, which becomes miss-information. People are expendable. 'There is no sense of the common good'

Social, psychological and communication globalization: This aspect of globalization is at the service of the previous three types. it is based on the computer, the e-mail, the 
Webside, the video, the cellular mob ile phones, fax and so on. The discovery of these modern means of communication have both good and negative sides. Once they are used to discourage people from thinking, making them rely on getting everything on the e-mail, already prepared outside; when research moves away from libraries and from the people themselves and sought on the Webside only; when people dis like creativity and originality and depend solely on these modern means, then the mind is socially and intellectually blinded. There is now very little time for individuals to think originally. The time that exists is to visit all the websides available and get all the material one needs from them! People are bombarded with massive material to discourage thinking. When one is fully 'married' to this new technology, he or she will simply imb ibe in knowledge and information designed and conceived by others. Once one's mind is so controlled, globalization wins fully!

Some Positives elements of globalization: In case you may be already thinking that I am anti-modernity, fully pessimist about the whole of globalization, backward and negative traditionist, a prophet of doom. Let me assure you I am not any of the above. 1 stand in the extreme middle, trying to balance the positive with the negative features of globalization. I try to use the former, and completely reject the latter. Once basic thing I have learnt in life and through suffering and pain is never to let people or things or circumstances think for me. They can only encourage and help me to think!

\section{Values to Appreciate}

World peace and peace everywhere: The United Nations and all their organs were created from 1945 onwards, following the great shock of the Second World War. The UN Charter of 1945 aimed at eliminating world wars and others wars from the surface of the earth. People everywhere were to live in peace and peacefully with all, without racism, religious bigotry, intolerance, prejudices, tribalism, oppressive ideologies. All human beings were to regard and treat each other as sisters and brothers in the one human family of the world. Where globalization is based on this peace- principle for every nation, every group and every individual, I am fully in great support. Globalization as a peace-movement the worldover, a movement for peace-keeping where peace exists, for peace-making, where peace is absent, for peace-education and promotion everywhere and for promoting a world culture of peace, then it is positive and should be fully supported.

Globalization as promotion and defence of universal human rights: human rights have been agreed to by the nations of the world as the minimum basis for peace and justice in the world. When globalization promotes these values everywhere in the world using the same measure, although taking into account local situations, it is a positive move.

Globalization as a human instrument for world understanding: among nations and people is positive. Oppressive barriers must be removed and nations would deal with one another in mutual respect and understanding. We are all citizens of the world, which God created without borders. These borders are human-made. A citizen of one country, if his or her life is in danger, should remove anywhere else and be accepted, not only as a refugee but later on as a citizen. Nobody in this world can ever justly sentence a person to be without nationality or citizenship.

Globalization for the defence and liberation of children and other vulnerable groups: When globalization is for the defence of the rights for children, wo men, persons with disabilities, refugees, the old the sick, workers and minorities, it is a positive movement. It is aimed at eliminating oppression and injustices, long built within cultural conceptions and historical realities. Globalization can then be useful in putting an end to child labour, child-slavery still going on, child prostitution, and child pornography. It would do similar good things for each of the other vulnerable groups.

Globalization and liberating and empowering education and in formation: As Paulo Freire already asserted in the early 1970s, (4) no education is neutral. It is either for liberation or enslavement, for empowering or accepting the status quo, for development and self-reliance or for underdevelopment and feed ing on reliefs from the rich. If the information and education linked with globalization using all modern techniques of the new computer age is for liberation and empowerment then it is positive.

Globalization and scientific research and experiment geared to better human life and better world: where this exists then it is positive. But where Malaria continues to kill millions of Africans, and where measles kill millions of children in this age of very sophisticated global village with lots of scientific skills, then there is a fundamental problem on the ultimate aim of such scientific researches which are not geared to a better human life and a better world.

When globalization is a vehicle for equalization of opportunities for all and social and affirmative justice for the vulnerable groups then it is positive (5). Until the global financial institutions, policies, conditions of trade become just and therefore beneficial to the poor, and the vulnerable, g lobalization will not be positively viewed by the victims.

\section{Working Definition of Globalization}

It is from the above views that I may now define cultural, religious, psychological and scientific movement or trend aimed at advancing and achieving a cosmopolitan mind in values, needs, and conceptions for mainly the advantage of the rich and the initiators of this process from the West, but with several key values for all.

\subsection{The Process of Incultur ation}

- If inculturation is to effectively controlled, critically 
judged and profitably utilized globalization, then it should be fully empowered and dynamically perceived. Inculturation, within the Africanscene, has several given conditions which globalization has no power to change fundamentally. It is in a time of identity crisis and presence of overwhelming foreign influences that enculturation comes out very strongly to re-assert its basic and fundamental elements. I wish to single out only a few of these, leaving the rest to the participants.

- The black colour or blackness of the Africans is a given element, uniting blacks in African and in the Disapora. This blackness cannot be globalized since the societies at the steering of globalization have black people within them who are marginalised and therefore not at the core of globalization. This blackness has a value and a long and bitter history, which cannot be globalized. Those black Africans taken to Europe and America since centuries continue to be black after numerous generations. So me may have very light colours, some rather light, others very black. But they are all blacks in classification. It is Inculturation, which can fully exploit the beauty of blackness, the equality of blackness everywhere, without racism. I cannot conceive any meaningful inculturation in Africa without the value of blackness. An African may try to paint himself or herself white or brown, but he or she remains black and is considered and regarded by all as black. The age of globalization should make us rediscover more what this blackness stands for, what it is advocating for and how its identity can and should be and defended (6).

- This is inculturation.

- The history of the black people and of Africa as a continent has its rich biblical exodus, in the bitter and shameful story of slavery and slave trade. No genuine African theology can be developed without deep roots in this black history. The Black theology, developed in both Americas, Caribbean Islands and South Africa, is an integral part of inculturation. However powerfully globalization forces itself on Africa, there is no way it can kill black theology, rooted in the historical reflection of the African people. The descendants of African slave parents, of the African chiefs who sold slaves, and of the victims of that slave trade can never forget the bitter history of the African continent. This episode of Exodus becomes a centre in their thinking and planning the way forward. No genuine theology can be built on forgetfulness. It is based on remembering. God's people are those who remember who they are, what they were and how God's hand was stretched to liberate them. All the five stages of oppressive globalization mentioned earlier become sources for this theology of remembering, and it is the African theology of liberation. No one else who has not experienced this through the lives of one's ancestors can ever develop such a theology. Timid globalization prefers emphasizing forgetfulness, but inculturation will continue to stress remembering so that our history becomes part of our present and future.

- The worldview of the Africans is an essential part of the m whether they live abroad, in Capital Cities full of globalized realities, or in international communities which demand a beautiful Mosaic culture. Globalization at the mo ment is strong only in the external realm. Its cosmopolitan impact on internalized worldview is still and likely to be very little. The worldview, as we all know, is the basis of developing a relevant and dynamic inculturation theology, which parts from a people's heritage (8).our own times, the African village and ru ral society will not change much from what it is now. It has been so for centuries and there is no indication that globalization is about to change that. Change and the rapidity of change do not simply happen anywhere, even when the features of globalization begin to be amidst the rural Africans.

- The African context, whether economic, political, religious and social is to remain different from the contexts of other continents. This is one reality that globalization has ensured for African. The poor are becoming poorer. The landless are increasing. Diseases, including the very mysterious ones such as Ebola are resurfacing in the Continent. Refugees and internally displaced people are multiplying. Religious fundamentalism is on the scene in many areas. Underdevelopment is felt in many parts. The quest for liberation will continue and the oppressed will continue to work for their full liberation. In such circumstances, African contextualised theology (9), aimed at analyzing the various contexts we live in and making Christianity fully relevant to it will necessarily continue and globalization will be part of those oppressive contexts which must be analyzed by African theologians and African Christianity.

\section{The Models of Inculturation}

Since I studied Stephen Bevans's book, Models of Contextual Theology, (Orbis, 1992) my understanding of inculturation and the models it must use changed radically. When one reflects on the five models provided by Bevans, one would understand that globalization has no power of undermining inculturation, properly understood. It can simply provide one of the contexts for inculturation to take root, and be appreciated.

\subsection{The Translation Model}

This model the oldest, the easiest and the most popular, starts from the top to the bottom, from the given Faith to local cultures, from what the ecclesial centre has prepared to putting that into a language local people can understand; from universal symbols to search for the local equivalent. This is the old deductive model, which begins from the 'universal' principle to local applications. This model is easy and simple and non-controversial because its main function is to trans late what is already given, without challenging it or fundamentally modify ing it.

When the Bible is translated into any local language, when the entire Roman Missal and rites of sacraments are trans lated into local Languages, when the Christian doctrines 
are translated into local languages, translational inculturation is taking place at the level of language to make Christian Faith understood by all. When students of theology write theses comparing the Eucharist to African models of sacrifice; Christian priesthood with priesthood in the ATR; the sacrament of Baptism with the African ceremony of naming; Christ with the African Ancestors and so on, what is being done is translation inculturation.

This Translation model of inculturation has strengths and weaknesses. The strengths include respecting the right of all people to their language and to knowledge of the Faith in their own languages for active participation and conviction of the Faith. The weaknesses include often using literary translation, making little meaning to the hearers; failure to use extensively the local terms from the ATR, for fear of 'syncretism' or giving the wrong impression. Many translators decide to use foreign words and concepts under the guise that language is always dynamic and these foreign words would one day be accepted by the local people. The foreign words still maintained in most of the African languages include:-

Sacrament, grace (ennema), Bikira (Virg in), A men, Alle llu ia, Missa (Mass), Sacerdoti (Priest), Kaliisa (Chalice), names of most of the vestments, utensils used for liturgy: and numerous other expressions, at the centre of understanding Christianity. Many translators fear to enter the area of African proverbs, wise sayings, stories and rich expressions. Those who compare sacraments or doctrines within Christianity and those within the ATR tend to remain superficial and fearful to go deeper enough. The result of all this means that even this Translation Model has never been carried far enough. A lot needs to be done to make the meaning fully understandable to the people it is meant to help .

Globalization is not going to impose one universal language for all peoples. Even if it tried it will fatally fail as the experiment of Espiranto as a universal language failed right from the start in the early 1950s. People will not be turned into robots. Diversity will remain, and not only in external realities but also in inner realities of people's perceptions, thinking, values and mentalities. I see no threat therefore to inculturation from the globalization process in this perspective.

\section{The Anthropological Model}

This model in a way is the opposite of the foregoing on. Its point of departure is the people and their culture and cultural heritage. It starts from the known to the unknown. It follows the educational and pedagogical approach. Because of this it is more effective, more daring and challenging and more difficult. It requires much creativity, research, freedom and courage from the African theologians. It poses fundamental questions and critically studies historical Christianity to separate the essentials from the contingents.

In inculturating the Eucharist as a festive meal, the start is on how the people of the place prepare such a feast; how they divide roles-who does what and when?, who and what should be present? What should start, be in the middle and at the end? It is when this is well established with the African consensus that the inculturating community refers to the given, to marry the two. The results, the impacts of such inculturation are far-reaching. People who have been Christians for decades can be heard saying: 'We had never seen or heard or participated in the like before. Now we can say, the Faith fully belongs to us. We can fully partic ipate in the Mass. This celebration has radically changed our lives'. If we are still far from that, the reasons are continuous use of one model, the Translation Model. The moment fear is cast away, more freedom enjoyed, more creativity used, and the Anthropological model emp loyed, we shall see inculturation grow and bring the positive results envisaged.

I fail to imag ine how positive globalization whose nature must respect legitimate diversities and whose success must require relevance to every situation can be opposed to the anthropological model of inculturation. Should the Universal church wish to negatively use globalization to further its overcentralization, it would be negating the major principle of Vatican II of building the universal Church on the autonomy of local churches with all their diversities. The human right to be different needs more emphasis in the age of globalization. In fact, globalization in many ways advances this right, since people are often bored by uniformity and react by enjoying only what is different (13).

\section{The Praxis Model}

This model is very important. It parts from the praxis of Christianity and religion in general in any given locality and moves to theologize. In this model it is the pastor living among the people. The catechist in the community, the parents in the domestic church, the family, the chapla in in the school or hospital $r$ any other institution who become the major agents of inculturation. It is their conrete observations on how the Christian faith is lived, the tensions found, the dualism, the dichotomy discovered that become the major source of inculturation. It is a useless inculturation which does not begin fro $m$ the concrete experience of the people or community. Genuine theology of inculturation must spring from the people at the grassroot, their popular religiosity Faith and the popular practices and tensions in the community.

As long as lnculturation is perceived as having been 'fabricated' from "closed" seminaries and faculties of theology, it will carry very little impact. But when these institutions become bases of analy zing what is taking place, what is being done, what is being perceived, the questions being asked and the answers being searched for, the these institutions have a role in inculturation.

When the Christians Faith is presented to any people, there is an engaging response. What is given is never taken by the converts in totality. It is weighed, accommodated, modified, 
challenged, and even changed in accordance with the mind and reality of the receiver. Th is is the challenge of the praxis model (15).

A theologian of the praxis model asks such questions before developing his or her theology: What do this or that people say God is to them? Who is Jesus Christ to them? What is the Church to them? What is Christianity to them? How are they living it in their lives, in normal times and more so in abnormal times? How do they use the Bible and Bible teaching? What teaching most touches their lives and is appreciated? What do they dislike most in Christianity? What do they ignore, without telling Church leaders? What do they find re levant and irre levant? What type of integration have they made themselves?

However strong globalization becomes, it cannot silence these questions nor become opposed to discovering the praxis at the level of each community and people. What can in fact happen is that signs of globalization will make these questions sharper.

\subsection{The Synthetic Model}

This is the model most related to globalization. It does not need foreign globalization to be in place in order to operate. This mod\& recognizes that in the effective evangelization of the African family, a theologian should be synthetic. Within the family one has parents, children of all ages, relatives, friends, neighbors of various relig ious denominations, values and perceptions. The aspirations, expectations, problems and fears of these members do differ. It is not a homogeneous family. In developing a relevant theology of inculturation for the family, one has to use the synthetic model to be inclusive and cater for everyone who is part of the family.

In every community, parish, diocesan and national Church, members are not homogenous. Because of immigration, people of various ethnic groups live together in all those communities. Because of mixed marriages, members belong to different Faiths. Their occupational lives differ and their level of education is different. It is the synthetic model of inculturation, which helps the pastor, and the theologian to be relevant and effective to the entire community.

In our African Cities the reality is even much complicated. Different races live together; the urban poor are with the urban rich; the oppressors attend the same Church with the oppressed; the illiterates are side by side with the educated elites; the rural members constantly come to live with their 'successful' city dwellers. Nairobi, Kampala, Dar-es-Slaam Lusaka, Accra, Abuja, Addis Ababa, Pretoria, Lilongwe, Harare, Khartoum and others are good examples. A rural pastor, not trained in cosmopolitan urban apostolate may find himself or herself lost in any of our major Capital Cities. $\mathrm{He}$ or she will search the seminary notes and the inculturation notes and find nothing helpful in the new situation.

Globalization tells us to expect peoples from various cultures and thinking to be part of our communities, especially in the urban areas. These reality challenges the way we make our pastoral timetable and programme; the way we inculturate the worship: the way we respond to the concrete needs and expectations of each and every member of the church. Very few African theologians are parting from the plural religious praxis within the community. Many still think that the dominant ethnic group in the area they serve should be the only one focused at. This is where fundamental change is needed to fully utilize the Synthetic Model of inculturation to make everyone feel at home

The current globalization should provide us with a rare chance to think seriously about the heterogeneity of our communities and come up with such inculturation, which meets the expectations of all. The major challenges here include eculturating the new people within the dominant community: sensitizing the dominant community to positively accept and appreciate the diversities other people bring and forming a beautiful Mosaic in the community. Some people have called this Inter-culturation. But here it is referred to as the Synthetic Model of Inculturation. The more the 'global village' is put in place the stronger the challenge to adopt this model. True Catholicity should cater for all and for each in an inclusive manner.

\section{The Transcendental Model}

One of the basic reasons why after 50 years many church leaders, theologians and Christians are still asking themselves whether inculturation is good or bad, effective or simply academic, fundamental or simply optional, is our failure as theologians to emphasize the Transcendental Model of Inculturation. The very term 'inculturation' is always rejected by our globalized Computers! Th is by itself poses the question of why after 50 years of inculturation the Computers cannot understand this terminology!

The transcendental model emphases the need to begin inculturation from liberating the minds of the stakeholders. To appreciate inculturation one has to fully know what it is; what it aims at achieving; what the results would be. Inculturation must go hand in hand with liberation of the mind and attitudes. As long as the minds cannot move from the status quo to something more dynamic, inculturation cannot be appreciated nor understood.

The people whose minds should be liberated are not simply the theologians themselves, but also the church leaders, the lay leaders and the Christians at the grassroots. Inculturation works only where it is believed in as a value. Many old Christians and Pastors are often heard saying: 'I am too old to change. What you suggest may be good for the young ones, but not for me.' We sacrificed so much to embrace this Christianity, we were isolated from the community. I have grown up knowing that being a truly Christian in this community means not being part of the community. I cannot change; I can not appreciate your moves to make Christianity related to the former ATR which we completely disowned and became new creations in Jesus Christ.'

The Transcendental Model of inculturation concentrates 
on liberating the minds of Christians to critically evaluate what they were taught and to become free children of God who wishes that $\mathrm{He}$ is worshipped in love, and freedom, using their own heritage and mentality rather than in slavery and fear.

The more g lobalization will show itself and its force in Africa, the more the need for transcendental model of inculturation will be felt. Religion is a free choice. People who have made that choice should worship God in love and freedom, and not in fear. Few African theologians have concentrated on this model to bring out the fears Christians have; the origin and causes of that fear and the enslavement they feel in Christianity and without the courage to express them openly.

Globalization, if based on the positive values, should stand for the freedom of each people to worship God in the best way they freely feel. Should globalization force people to adopt one way of worship, or being Christians then it will clearly present itself as colonial, oppressive and out of touch with the current rea lities.

\section{Inculturation and the Mission}

Inculturation principles are at the core of the constant and regular definition of who subject of evangelization are, the context in which they live and work, the priorities of their evangelization, the vision and the strategies, methods and principles or means to be used. It is within such context that the impact and effects of globalization, both positive and negative, are critically examined and taken into serious consideration in the struggle to be relevant and to adequately care for those marginalised and made vulnerable by the globalization process (20).

\subsection{Enculturation and the Mission}

The Mission in this context refers to the subjects of evangelization. It tries to define who the Africans of today are; and who African Christians are; who the African Catholics are; who the poor and the vulnerable are; and who the agents of evangelization are. The way we define the evangelizers and the evangelized determines much our manner of approach and our relevance or irrelevance. The Mission also defines the real context of the Africans, which must be evangelized. The manner in which such a critical analysis is done in Africa is determined by inculturation. The questions asked, the methodology used in such analysis cannot exactly be the same as those used in other continents. The reason is simple. Any credible social analysis must respect the worldview of the people among whom it is done. If our church and our theology are often considered irrelevant, static and far from the very reality on the ground, one of the main reasons is that it has failed to define the Mission critically enough. Without fully knowing the joys and hopes, the aspirations and expectations, the fears and anxieties, the problems and tensions of the subjects of evangelization, inculturation cannot take place and evangelization can only be superficial.

\subsection{Inculturation and the Mandate}

The Mandate here defines the essential Ministry of Christianity, of the Catholic Church and the local churches. This Mandate: in whatever way it is defined, must always be dynamic. pro-life, pro-people, pro-liberation, and prorelevance. It is the liberation-inculturation model that can regularly enable us to define the Mandate adequately. Without doing so our seminary formation may became archaic, our priorities in evangelization may not be those of people the faith is meant to liberate and inspire integrally. It is inculturation that can involve all people to play their active part in this Mandate, which up to now is narrowly defined as being for the clergy, religious and catechists mainly! All the essential elements of this Mandate must by fully inculturated: Proclamation (Kerygma), service (diaconia), worship (leiturgia), Love (agape) unity, solidarity, justice and peace (Koinonia), witness (marturia), liberaration and development.

\subsection{Inculturation and the Vision}

Defining the Vision to be targeted by the people of God at any given time requires use of the inculturation models. A church, a local Christian community, without vision is without a clear future. This vision to be realistic, attractive, participatory aimed at, needs a good homework based on the above two givens: Mission and Mandate. No living church can ever afford to be simply with two mo ments: the past and the present. To be a living Christian community we need all the three moments: the past, in order to remember, since Christianity is a historical religion; to fully live the present in order to be relevant; and the future, to aim at achieving a vision which has been arrived at through participatory and democratic consultations and decisions of Pastoral Councils, diocesan

Synods, national Synods which are fully representative of all sections of God's people.

\subsection{Inculturation and the Ethos}

No Vision can ever be achieved without clear definition of the means, the methods, the strategies, the principles, the logistics, the human resources and the time-management. It is in this field that inculturation provides great guidance and insights. The African church cannot simply imitate or copy the means and strategies used elsewhere. It has to be innovative, creative and original. I may single out some fundamental sources for this ethos in African Christianity today.

Our rich cultural heritage is a major source of the ethos. Look everywhere in history, you will never find any civilization which has been built on borrowed values or heritage. The more some of us think that African Christianity can be constructed on entirely borrowed foreign cultural heritage the more we fail Africa and the African church. The strengths of our cultural heritage must be fully exploited as 
powerful means or ethos in our evangelization. We should extensively use the SWOT method of analysis (strengths, weakness, opportunities and threats) of our cultural heritage in - order to use it fully in current evangelization.

Church-as-family-of-God based on justice and peace, human rights and respect, inculturation and liberation, Dialogue and effective communication is a challenging model of church, the African Synod came up with. This ecclesiology can and should become an ethos in our evangelization. Whether the African Bishops were fully aware of the liberating power of this model or not, what the Holy Spirit inspired them must be fully utilized. In this model the church in Africa is built on the African modeled on the best values in our family cultural heritage, must positively respond to the tensions existing in the African Christian family and marriage. It must manifest a clear option for the poor and the vulnerable. Here we have an approved ecclesiology to develop and explo it in this age of globalization.

The new positive movements at work in Africa: These movements include, among many, the women liberation, democratization, participation, human rights, especially of the vulnerable groups, accountability and transparency, new means of communication and so on. These movements should be used as means for our effective evangelization. They should be inculturated to make real sense in Africa

\subsection{Training and For mation of $S$ pecialized $P$ astor al Agents}

Inculturation will not take root as long as the training of specialized agents continues to marginalize it. These agents are the living and human resource for inculturation. They are part of the ethos and strategies as well as part of the Mission, Mandate, Vision.

\section{Conclusions}

It is my strong belief is that inculturation in Africa and within the Catholic church to stay, with or without globalization. It is a divine mandate, used by God to liberate His People, to send his only Son to become one of us in history and share human culture in a specific environment. Jesus incarnation will always remain the fundamental basis of any genuine enculturation. Inculturation is taking on an even greater importance in the age of globalization to positively resist any oppressive uniformity and the making of people robots! Inculturation is to stay because it aims at relevance, dynamically understood and imp lemented. It will stay because it is instinctinsticly linked with liberation. The challenge, therefore, is to affect the 'marriage' between the two in such a way that Africa and the Africans, the Church and the African Christianity, the vulnerable people are the winners and never the losers. To be able to do this we need the conviction that the choice of the African church is either to inculturate effectively or die out (21)! We are all part of making this choice. I wish we au choose unculturation rather than letting Christianity, for which numerous ancestors have laid down their lives, die cut in Africa. As indeed it did in the early centuries and in the age of exp lorations! Thank you for your attention / a wait your contribution and challenge.

\section{REFERENCES}

[1] Abraham K.C. (ed) Third World Theologies: Communalities and Convergences, N.Y.Orbis, 1990

[2] Achebe, Chinua, No longer At Ease, London, 1960

[3] Achebe, Chinua, Things Fall Apart, London, 1958

[4] Amaladoss, Michael, (Ed) Globalisation and its Victims as seen by its Victims, Cambridge Press, Delhi, 1999

[5] Bahemuka Mbula Judith, Our Religious Heritage, Nairobi 1982

[6] Barret, David, (ed) African Initiatives in Religion, Nairobi, 1971

[7] Barret, David, Schism and Renewal in Africa: Analy sis of six thousand contemporary Religious Movements, Nairobi, 1968

[8] Bevans, Stephen B., Models of Contexual Theology, Orbis, 1992, New York

[9] Bosch, D. Transforming Mission: Paradigm Shifts in Theol ogy of Mission, N.Y. Orbis 1991

[10] Cone, J.A. Black Theology of Liberation, N.Y. Orbis, 1986

[11] Gatheru, Mugo, The Child of Two Worlds, Nairobi, 1969

[12] Gifford, Paul, African Christianity, Its Public Role, London, 1998

[13] Gittins, A.J. Gifts and Strangers: Meeting the Challenge of lnculturation, N.Y. 1989

[14] Hastings, Adrian, African Christianity, London, 1976

[15] Hastings, Adrian, African Catholicism: Essays in Discovery, London, 1989

[16] Hastings, Adrian, The Church in Africa, 1450-1950, Oxford, 1994

[17] Hastings, Adrian (ed), The Oxford Companion to Christian Thought, Oxford, 2000

[18] Idowu, E.B. African Traditional Religion: A Definition, London, 1974 